\title{
AN ANALYSIS OF STUDENTS' ERRORS IN PRONOUNCING ENGLISH DIPHTHONGS AT THE FIRST SEMESTER OF STAIN JURAI SIWO METRO
}

\author{
Much Deiniatur \\ Institut Agama Islam Negeri (IAIN), Metro \\ Email: deiniatur@gmail.com
}

\begin{abstract}
The objectives of this research are to find out total errors of the student when they pronouncing English word containing diphthongs, to find out what type of diphthongs that students made the most frequently mispronounced, to find out what type of diphthongs that students made the least frequently mispronounced, and to find out the factors influencing error pronunciation that the student made in English word containing diphthongs.In this research the writer used qualitative method. The subjects of this research were 40 of the First Semester students at STAIN Jurai Siwo Metro in academic year 2015/2016. The instrument of this research was a pronunciation test of the English word containing 9 types of English diphthongs, and voice recorder to record the students' pronounciation. The data of this research were collected by giving the English pronunciation test. The collected data were identified, classified, analyzed and interpreted.. The results of the analysis showed that the students made errors out of the total 499 words. The types of diphthongs that the students the most frequently mispronounced are [ov] (62 words), [av] (61 words), [चə] (59 words), [əə] (59 words), and [عə] ( 58 words),.The type of diphthongs that the students the least frequently mispronounced is [aI] (46 word). The factors influencing error pronunciation that the students made are the habit of students in pronouncing the word that contains of diphthongs and the students pronounced the word as it was written in the orthographic writing.
\end{abstract}

Keywords: Error, Pronunciation, diphthongs

\section{INTRODUCTION}

Nowadays, mastering other languages, especially the International language, namely English is very important since language is a means of communication among individuals. The process of globalization and modernization will actually bring people to live together in a global life in the world. The need of interaction with people in a global society who have different backgrounds, languages, and cultures cannot be avoided. Thus, the international language function as the main means used by English speaking people to interact with each other and build a relationship with their community. However, so many English learners meet difficulties in oral communication. It is also happened in English Education of STAIN Jurai Siwo Metro. There are many factors that influence pronunciation fluency, among many other factors, the most 
prominent is phonetic, which to a large extent, weakens the learner's confidence in speaking.

Learning a foreign language, especially English, may have several kinds of learning problems. These problems are related to the learning of the sound system, the learning new vocabularies, and the learning of unfamiliar ways of arranging the foreign words into sentences. To begin our study of English language starting with a consideration of exactly how human beings are able to communicate with one another using speech. The most logical way to begin is by focusing on speech sound. Charles, (1991 : 27) believes that the study of the sounds that we produce when we engage in spoken communication is called phonetic.

Pronunciation is a very important element of foreign language learners. There are so many problems with understanding English spoken at a natural speed by native speakers who speak with various accents. Non-native English also have problems in speaking to and being understood by others. Some students still have problems. One of the problems is dealing with phonetic understanding. Because every English learner has their own phonetic words dealing with their native language such as Javanese, Indonesian, Chinese, Japanese, etc. (Rebecca et al, 2003 : 4).

\section{LITERATURE REVIEW Definition of Phonetics}

Phonetics is the branch study of phonology instead of phonemics as Ramelan (1999 : 1) said that the study of language in general (which is called linguistic), may be subdivided into two main terms, phonology and grammar. Phonology is the study of phones or speech sound, while grammar is the study of meaningful units of sound system and their arrangement into larger utterance.

Phonetics on the other hand is the systematic study of the sounds of speech, which is physical and directly observable. Phonetics is sometimes seen as not properly linguistic, because it is the outward, physical manifestation of the main object of linguistic research, which is language (not speech): and language is abstract. (Ogden, 2009:1)

Pronunciation is defined as the way in which languages or words are spoken (Manser, 1991 : 330). It's also dealing with the way in which someone speaks of foreign language. Learning a second or foreign language will face many kinds of obstacles. It is dealing with the new words, new grammar rules. Pronunciation as one matter of learning new languages plays an important role in learning the target language since it is the way of sounding those languages. Pronunciation is translated into Indonesian as "melafalkan" which has the noun from "lafal". In Kamus Besar Bahasa Indonesia Pronunciation means the way of persons or community of language in speaking the sound of language (Depdiknas, 2007 : 237).

From the definition above, the writer tries to define that Pronunciation is the way a word or a language is spoken, or the manner in which someone utters a word. 


\section{Pronunciation Problems}

According to Ramelan (1999:8), there are some Pronunciation Problems faced by Indonesia students:

a. The identification of the foreign sounds.

This means that the student has to remember their acoustic qualities so that he will be able to directly identify them in utterance.

b. Production of the foreign sounds by his organs of speech.

Ability in hearing and identifying the acoustic quality of the foreign sounds is prerequisite for the ability in producing them.

c. Production of suprasegmentals features like stress, length, pitch, and intonation.

It is quite obvious that these features cannot be overlooked by the students because they are almost always different in different languages.

\section{Diphthongs}

Ramelan (1999:59) states that a diphthong is a vowel sounds in which there an intentional glide is made from one vowel position to another vowel position, and which is produced in one single impulse of breath. According to Ogden (2009: 64), Diphthongs are monosyllabic vowels which have two discernibly different points, one at the start and one at the end. Most varieties of English have several diphthongs.
Table 1 Diphthongs Sounds

\begin{tabular}{|c|c|c|c|}
\hline No. & Symbols & Key-words & $\begin{array}{l}\text { Phonetic } \\
\text { Writing }\end{array}$ \\
\hline 1. & [eI] & Day & [deI] \\
\hline 2. & {$[\mathrm{ov}]$} & So & {$[\mathrm{sov}]$} \\
\hline 3. & [aI] & High & [har] \\
\hline 4 & [av] & Cow & {$[\mathrm{ka} \sigma]$} \\
\hline 5. & [эI] & Boy & [bor] \\
\hline 6. & [Іә] & Here & [hıอ] \\
\hline 7. & [عə] & There & [ðعə] \\
\hline 8. & [ชə] & Poor & [pøə] \\
\hline 9. & [ə] & Your & [уоә] \\
\hline
\end{tabular}

\section{Error Analysis}

Brown (1980:166) states that error analysis is the fact that learner do make errors and that these errors can be observed, analyzed, and classified to reveal something of the system operating within the learners. The purpose is to show some problems faced by the students. It is a key to understand the process of foreign language acquisition.

Ellis (1997: 15) writes that there are good reasons for focusing on errors. First, they are a clear feature of learner language. Second, it is useful for teachers to know what errors learners make. The last, it is possible that making errors may actually help learners to learn when they self-correct the errors they make.

\section{RESEARCH METHOD}

This research uses descriptive qualitative method to search the answer of the objective of the study that is to describe what diphthongs mispronounced by the students, by collecting, analyzing the data, and drawing conclusion based on the data analysis. They cannot be expressed in number, but in sentences. Qualitative research is a research that produces a procedure of analysis. It does not use a statistical procedure of 
analysis or the other quantitative method (Moleong, 2010: 6). Basically, the purpose of descriptive research is to record exactly what happened, whether the researcher is describing an experimental treatment or something occurring in the natural habitat of study participants.

The procedure of collecting the data were as follows:

a. Pronunciation tests were distributed to the students.

b. The students were asked to read the instruction.

c. The students were asked to pronounce the pronunciation test items (English words).

d. The pronunciations of the students were then recorded.

After finished the pronunciation test, the recorded data were analyzed. This activity was conducted on December 2015. The writer chose the Class B of first Semester at STAIN Jurai Siwo Metro. The class consisted of 40 students.

\section{DISCUSSION}

Pronunciation test are purposed to know the students pronunciation, especially in English diphthongs. There were 18 diphthongs pronounced by 40 students.

Table 2 Diphthongs Sounds

\begin{tabular}{|c|c|c|c|c|}
\hline No & Symbols & $\begin{array}{l}\text { Key- } \\
\text { words }\end{array}$ & $\begin{array}{l}\text { Phonetic } \\
\text { Writing }\end{array}$ & $\begin{array}{l}\text { Number } \\
\text { of errors }\end{array}$ \\
\hline 1. & [eI] & Day & {$[$ deI $]$} & 26 \\
\hline 2 & [eI] & Race & [reIs] & 25 \\
\hline 3. & [ov] & So & [sov] & 32 \\
\hline 4. & [ov] & Code & [coud] & 30 \\
\hline 5. & [aI] & High & [haI] & 25 \\
\hline 6. & [aI] & Rice & [raIs] & 20 \\
\hline 7. & [av] & Cow & {$[\mathrm{kav}]$} & 30 \\
\hline 8. & {$[\mathrm{a} v]$} & Foul & [faol] & 31 \\
\hline 9. & [OI] & Boy & [bor] & 25 \\
\hline 10. & [OI] & Voice & [vors] & 26 \\
\hline 11. & [Іә] & Here & [hıə] & 28 \\
\hline
\end{tabular}

\begin{tabular}{|c|c|c|c|c|}
\hline 12. & [Іә] & Fear & [fIə] & 25 \\
\hline 13. & [عə] & There & [ðعə] & 30 \\
\hline 14. & [عə] & hair & [heə] & 28 \\
\hline 15. & [णə] & Poor & [рvә] & 30 \\
\hline 16. & [Uə] & Tour & [tuə] & 29 \\
\hline 17. & [००] & Your & [уюә] & 30 \\
\hline 18. & [००] & Cores & [cors] & 29 \\
\hline total & & & & 499 \\
\hline
\end{tabular}

The errors in pronouncing English diphthongs are assumed to be affected by many factors. One of the factors is the habit of students in pronouncing the word that contains of diphthongs. The habit can be from imitating, mishearing, and mispronouncing. The second is because the students pronounced the word as it was written in the orthographic writing.

The habit in pronouncing a word can be affected by imitating someone in pronouncing that word. The students are disposed to imitate someone whom they believe in perfectly. It can be a teacher, an actor or actress in an English movie, the English singer, or the others. Error in pronouncing words happens when they copy the wrong models.

Besides imitating, mishearing can be a main factor in pronouncing errors. It happened because the students were not used to hearing words, especially certain diphthongs, in their native language. Their ears must be trained in hearing the certain diphthongs that do not exist in the native language. They must be trained again and again until they get familiar with them and remember their acoustic quality. Ramelan (1999: 8) claimed it as "ear-training".

When the students are not used to pronouncing certain words, they are disposed to pronounce the words as they are written in the orthographic writing form. However, the orthographic writing is not 
consistent to be pronounced. It sometimes represents more than one sound, such as letter $a$ in English, which represents different sounds in different words. (Ramelan, 1999: 9).

\section{CONCLUSION}

The results of the analysis showed that the students made errors out of the total 499 words. The types of diphthongs that the students the most frequently mispronounced are [ov] (62 words), [av] (61 words), [ซə] (59 words), [॰ə] (59 words), and [عə] ( 58 words),.The type of diphthongs that the students the least frequently mispronounced is [ar] (46 word).

Based on the result of the study, the writer would like to give some suggestion which hopefully will give valuable and useful contribution to the teachers and students in English pronunciations, especially in pronouncing diphthongs.

1. Teacher should:

a. Give more practice in speaking English to their students in order to make them more fluent in speaking.

b. Give more drills and practice to the students' in pronouncing diphthongs.

2. Students should:

c. Have good self awereness in motivating themselves to pronounce English words correctly. Such as: by reading an English book, novel or magazine, listening english songs and watching English movie. It might be helpful to improve their English pronounciation d. Look up the dictionary if they find some new vocabularies and try to pronounce it.

e. Have an English conversation either in the school, or in everyday life with their friends, teacher or other people who can speak English.

f. Give more attention to vocabulary, grammar, and pronounciation since learning English concern all of these skills.

\section{REFERENCES}

Brown, H.D. (1980). Principles of Language Learning and Teaching. New Jersey: Prentice-Hall Inc.

Charles, E. a. L. H., 1991. Kidder Research Methods in Social Relations. California: Harcourt Brace Jovanovich College Publ.

Depdiknas, 2007. Kamus Besar Bahasa Indonesia. Jakarta: Balai Pustaka.

Ellis, Rod. (1997). Second Language Acquisition. Oxford: Oxford University Press.

Hughes, Rebecca. (2002). Teaching and Researching Speaking. Harlow: Longman.

Manser, H., 1991. The Macmillan Dictionary of English Spelling. California: Macmillan.

Moleong, Lexy J. (2010). Metodologi Penelitian 
Kualitatif. Bandung: PT Remaja Rosdakarya.

Ogden, Richard. (2009). Introduction to English Phonology. Edinburgh: Edinburgh

University Press Ltd

Ramelan. (1999). English Phonetics.

Semarang: CV. IKIP Semarang

Press 